\title{
Yapısal ve İşlevsel Açıdan İngiltere ve Türkiye Yerel Yönetimlerinin Karşılaştırılması
}

\author{
Structural and Functional Comparison of Local Governments in England and in Turkey
}

\author{
Emine ÇELIKSSOY \\ Dr. Öğr. Üyesi, Çankırı Karatekin Üniversitesi, \\ IIBF, Siyaset Bilimi ve Kamu Yönetimi Bölümü, \\ eceliksoy@karatekin.edu.tr \\ https://orcid.org/0000-0001-8175-8611
}

\section{Aysena ALKAN}

YL Öğr., Çankırı Karatekin Üniversitesi,

SBE, Siyaset Bilimi ve Kamu Yönetimi A.B.D.,

alkanaysena@gmail.com

https://orcid.org/0000-0002-5416-9747

\author{
Makale Başvuru Tarihi: 07.07.2020 \\ Makale Kabul Tarihi: 01.09.2020 \\ Makale Türü: Araştırma Makalesi
}

\begin{abstract}
Anahtar
Kelimeler:

Yerel Yönetimler,

Hukuk,

Örgüt Yapısı,

Ingiltere,

Türkiye,

Türkiye'de yerel yönetimler diğer devletler ile klyaslandığında daha geç bugünkü anlamına kavuşmuştur. Tanzimat dönemi Osmanlı Devleti'nde bugünkü manada yerel yönetimlerinde ortaya çıktı̆̆ dönemdir. Üniter devletlerde kamusal mal ve hizmet sunumu merkezi yönetim ile yerel yönetimler arasında paylaşlmaktadır. Federal devletlerde ise federal devlet, federe birimler ve yerel yönetimler mal ve hizmet sunumunu gerçekleştirmektedirler. Birçok batıl devlette yerel yönetimler sivil toplum örgütü olarak ortaya çıkmıştır. Yerel yönetimlerin geçmişi ise orta çağa kadar uzanmaktadır. Ülkemizde ortaya çıkışı ve gelişimi ise kendine özgüdür. Osmanlı Devleti'nde de yerel hizmetleri yürüten birimler vardl ancak bu birimler Osmanlı idari sistemi içinde kendine has kurumlardl. Ingiltere'de yerel yönetimin ortaya çıkışı ve gelişimi ülkemizde ortaya çıkışı ve gelişimi farklı özellikte olduğu için mevcut durumda da birçok farklılıkları bünyelerinde taşımaktadırlar. Çalışmanın amacı eski ve köklü bir yerel yönetim geleneğine sahip olan İngiltere'deki yerel yönetimler ile ülkemizdeki yerel yönetimlerin karşılaştırmalı olarak hukuki ve örgütsel boyutlarının ele alınmasıdır. Çalışma literatür taramasına dayalı bir nitel araştırmadır. Karşılaştırma yapılmıştır.
\end{abstract}

Keywords:

Local Governments,

Law,

Organizational

Structure,

England,

Turkey,

\section{ÖZET}

\section{ABSTRACT}

Comparing to the other governments Turkey's local governments gain their present meaning later. Tanzimat reform era is the period when local governments have emerged in the modern sense. In unitary states, the duty of providing public goods and services is shared between centralized administrations and local governments. Wheras in Federal states, public goods and services are provided by the Federal state itself federated states and local governments. In many Western countries local governments have come out as nongovernmental organisations. The history of local governments goes back to the middle ages. Their emergence and improvement in our country is distinctive. In Ottoman Empire, there were also units which had conducted local services however these units were specific inside Ottoman administrative system. As the emergence and development of local government in England is different from our country in terms of feature, currently these two systems have many differences. The aim of the study is handling the legal and organisational aspects of local governments as a comparison between England which has a long and deep rooted history of decentralization and Turkey. This study is a qualititative research based on a literature review. In this study, comparison is made. 


\section{GIRISS}

Bir ülkenin idari yapısında yer alan ve merkezi idare (devlet) dışında kalan, ulus-altı düzeydeki belirli bir toprak parçası üzerinde yaşayan insan topluluğunun yerel ve ortak nitelikteki ihtiyaçlarının karşılanması amacıyla kurulan ve genellikle karar organları kendisini oluşturan halk tarafından seçilen kamu tüzel kişiliklerine yerel yönetimler (mahalli idareler) denilmektedir (Parlak, 2015:6). Yerel yönetimler, gerek demokratik hayatta oynadıkları roller, gerekse kamu hizmetlerinin halka götürülmesi noktasında sahip olduğu fonksiyonları sebebi ile yönetilenlerin yönetime katıldığı ilk aşamadır. Yerel yönetimler, merkezi idarenin yetkilerinin bir kısmını bazı yerel otoritelere devretmesinin ve mahalli bazı topluluklara bazı haklardan yararlanma hakkı tanımış olmanın bir sonucu olarak ortaya çıkmışlardır. Ortaya çıkmalarında da yine siyasi, idari ve toplumsal sebepler etkili olmuştur (Bayrakç1, 2019:15).

Ülkeler yönetim sistemlerini oluştururken genellikle merkezi idare (devlet) ile yerel (adem-i merkezi - mahalli) idarelerin bir arada olduğu karma yönetim modellerini tercih etmektedirler. Çünkü bu iki yönetim modelini diğerinden ayırarak, saf bir şekilde tek başına uygulamak günümüz şartlarında oldukça güçtür (Uysal ve Atmaca, 2018:414-415). Ülkelerin yerellik düzeyi, daha yalın bir ifade ile merkezden yerele aktarılan görev ve yetkilerin türü, içeriği, kapsamı, sınırları, etkinliği, özerkliği, vd. özellikleri ülkelere göre farklılıklar göstermektedir.

Devlet şekli olarak bir devletin "üniter" ya da "federal" yapıda olması, hükümet etme şekli, coğrafi büyüklüğü, nüfus yoğunluğu, demografik özellikleri, yönetim kültürü, katılım düzeyi, demokrasi kültürü, inanç sistemleri, ekonomik yapısı, komşu devletler ile olan ilişkileri, vd. özellikleri farklı oranlarda ülkelerin siyasal/yönetsel yapılarını şekillendirirler. Bu etkenlerin ülke yönetim sistemi üzerindeki etki oranları ülkelere göre ve içinde yaşanılan tarihsel döneme göre farklılıklar gösterirler. Bu farklılıkların karşılaştırılarak avantajlı ve devavantajlı yönlerinin ortaya konulabilmesi amacıyla çalışmamızda Avrupa kıtasının coğrafi açıdan farklı kısımlarında bulunan İngiltere ve Türkiye karşılaştırılmalı olarak incelenmiştir.

Üniter bir devlet yapısına sahip olan İngiltere güçlü bir yerel yönetim geleneğine sahiptir (İnaç ve Ünal, 2006:125). Bu geleneği güçlü kılan en önemli nedenlerden birisi, yerel yönetimlerin varlığının yüzyıllar öncesine dayanmasıdır. Magna Carta'dan (1215 Büyük Şart) bu yana İngiltere'de farklı formlarda da olsa yerel yönetimlerin varlığına rastlanılmaktadır (Oakland, 2002:65; Koçak, 2008:143; Arslan, 2018:2873). Yerel düzeydeki birçok kamu hizmeti, halka en yakın yerel birimler tarafından sunulmaktadır.

İngiltere'de, devlet idaresini yöneten hukuki ve hukuki olmayan kurallardan oluşan yasalar mevcuttur fakat birleştirilmiş ve tek bir yazılı anayasa metni bulunmamaktadır (Karasu, 2013:151). Buradan yola çıkarak İngiltere'de yerel yönetimlerin anayasal bir dayanağı olmadığı söylenebilir. İngiltere, yerel yönetimleri sürekli yeni düzenlemeler ile çağın gereksinimlerine uygun hale getirilmeye çalışılmış ve bu düzenlemeler bazen eleştirilere maruz kalmıştır.

Türkiye'de yerel yönetimler modern anlamda 1864 'ten sonra idari sisteme dâhil olmuşlardır. Türkler köklü bir yönetim kültürüne sahiptirler. Ancak modern yerel yönetim sistemlerini tesis etmeleri yakın zamanlıdır. Bu sebeple Türkiye'nin yerel yönetimler ile ilgili olarak İngiltere gibi uzun ve köklü bir geçmişe sahip olduğu söylenemez. Bununla birlikte 19. yüzyıldan önce yerel yönetimlerin yerine getirdikleri hizmetleri o dönemde sunan yönetsel mekanizmalar da vardı. Ancak bu birimler yerel yönetimler şeklinde örgütlenmemişlerdi. Osmanlı'da yerel hizmetleri sunan yerel birimler, merkezi idarenin yetkisi altında bulunmaktadır ve merkezden atanan görevliler eliyle yürütülmektedir (Çiçek, 2014:54). Cumhuriyetin ilk yıllarında yerel yönetimler alanında yeni yasal düzenlemeler hayata geçirilmiştir. Bunun birçok sebebi olmakla birlikte en önemlisi, Osmanlı'dan Türkiye'ye miras kalan güçlü merkezi yönetim anlayışıdır.

İngiltere ve Türkiye'deki yerel yönetim sistemleri karşılaştırılırken her iki ülkeninde yasalarla yetkilendirildiği kural ve kaidelere dikkat çekmek gerekmektedir (T.C. Kalkınma Bakanlı̆̆ı, 2014). İdari ve siyasi bakımdan köklü bir geçmişe sahip olan İngiltere'de yerel yönetimlerin merkezi idareden bağımsız ve genel yetkili idareler olduğu söylenemez. Türkiye'de ise yerel yönetimler merkezi idareden bağımsız ve genel yetkili idareler değillerdir.

Bu çalışmanın amacı; İngiltere ve Türkiye örneğinde yerel yönetimlerin karşılaştırılması ve her iki ülkede tesis edilen yerel yönetim sistemlerinin benzer ve farklı yönlerinin karşılaştırmalı olarak ortaya konulmasıdır. Çalışmada nitel araştırma yöntemi kullanılmıştır. Veri toplama araçları olarak akademik yazında yer alan makalelerden, kitaplardan, raporlardan, kurumsal web sitelerinden ve ilgili ülkelerin mevzuatlarından yararlanılmıştır. Elde edilen bilgilerin analiz edilmesinde; konuya ilişkin veriler süzülerek çalışmanın amacına 
hizmet edecek olanlar değerlendirmeye alınmıştır. Son olarak karşılaştırma yapılan ülkelerin konuya ilişkin benzer ve farklı yönlerine ilişkin özellikleri ortaya konulmaya çalışılmıştır.

\section{2. İNGILTERE'DE YEREL YÖNETIMLER}

\section{1. İngiltere'de Yerel Yönetimlerin Örgütlenmesi}

Günlük hayatta ve birçok akademik çalışmada Birleşik Krallık veya İngiltere olarak kullanılan devletin resmi adı Büyük Britanya ve Kuzey İrlanda Birleşik Krallığı'dır (Oakland, 2002:10). İngiltere'nin idari yapısında yerel yönetimler 1215 Magna Carta (Büyük Şart) ile başlamaktadır. 19. yüzyıl İngiltere'sinde yerel yönetimler yaklaşı 15 bin köy meclisi ve kasaba meclisinden oluşuyordu. 1835 yılında çıkarılan Belediye Yasası yerel yönetimler için ilk genel düzenlemedir. Çok amaçlı belediye ilçelerinin kurulması ve il meclislerinin yerel yönetimin temeli haline gelmesi 1888 Yerel Yönetim Yasası ile olmuştur. 1894 yılında çıkarılan Yerel Yönetim Yasası ile ilk seçilmiş şehir ve kırsal ilçe meclisleri kurulmuştur. Daha sonra 1899 yılında Londra'ya özel olan Londra Yönetim Yasası çıkarılmış ve bu yapı 1960'lara kadar devam etmiştir (Karasu, 2013:198). 1963 yılında ise Londra Yönetim Yasası çıkarılmıștır. 1965 yılı sonrasında Londra iki aşamalı yapısından kurtulmuş ve bütün bölge kentleri kapsayacak şekilde genişletilmiştir. Stratejik Büyük Londra Kurulu (GLC), 33 ilçe ve İç Londra Eğitim Otoritesi (ILEA) kurulmuştur (Yamaç, 2014:2).

1972'de yapılan ve 1974'ten itibaren yürürlüğe konulan Yerel Yönetimler Yasas1 ile mevcut yerel yönetim birimlerinin sayısı azaltılarak üç kademeli sistem oluşturulmuş ve bu şekilde yerel yönetimler yeniden düzenlenmiştir (İnaç ve Ünal, 2006:126). Bu kademeleri il (county), bölge (district) ve mahalleler (parishes) oluşturmaktadır (Karasu, 2013:198). 1985 yılında Yerel Yönetim Yasası çıkarılmıştır. 1986 yılında ise merkezi hükümet tarafından sistemin üst organı olan Londra Anakent Meclisi (Greater London Council) feshedilmiş, aynı zamanda fonksiyonları da yerel ve merkezi yönetim kuruluşu arasında paylaştırılmıştır. Muhafazakâr Parti Hükümeti (Greater London Council) bu kararın alınmasında çeşitli mali ve yönetsel faktörlerin etkili olduğunu savunmuş ve bütçede yer alan birçok gereksiz harcamanın olduğunu da öne sürmüştür. Bununla birlikte Muhafazakâr Parti hükümeti siyasi sebeplerle büyükşehir belediyelerini kaldırdığı noktasında şiddetle eleştirilmiştir. Londra'nın tekrar eski hale gelmesindeki ilk önemli adım 1993'te yapılan Yerel Yönetim Konferansı'nda atılmıştır (İnaç ve Ünal, 2006:128-129).

Seçimi kazanan İşçi Partisi 1998'de referandum yapmış ve Londralı seçmenler \%75 ile yenilikleri kabul etmiştir (BBC News, 1998). 1999'da Londra Anakent Belediyesi Yasası'nın onaylanması ile yasal düzenlenmeler tamamlanmış ve Londra Anakent Belediyesi kurulmuştur (UK Parliament, 2016).

Günümüzde İngiltere'de Londra ile beraber yedi Anakent Belediyesi bulunmaktadır. Bu belediyeler dişında il belediyeleri (shire counties) ve ilçe belediyeleri (shire districts) olarak iki kademeli sistem vardır. Üçüncü kademe ise mahalle meclisleridir (parish councils). İngiltere yerel yönetimlerinde halkın doğrudan belediye başkanı seçme hakkı yoktur fakat bunun tek istisnası Londra Anakent Belediyesi'dir. Belediyelerin meclis üyeleri kendi aralarından bir başkan seçmekte ve bu başkan çalışmaları düzenleme, meclisi temsil etme gibi işlevleri yürütmektedir. 1972 yılında yapılan düzenleme ile bu durum mahalle meclislerinde (parish councils) şu şekildedir; seçmen sayıs1 200 olan yerler Parish meclisleri oluşturma zorunluluğundadır, seçmen sayısı 200'den daha az olan yerler ise Parish Meclisi oluşturmada serbesttirler. Bu yerlerde halk y1lda en az bir kez toplanıp karar almaktadır. Bu toplantılara Parish Meetings adı verilmekte ve tüm seçmenlerden oluşmaktadır (Yamaç, 2014:7).

2011 Yerel Yönetim Yasası ile dört ana başlıkta temel önlemler açıklanmaktadır. Bunlar yerel yönetim için yeni özgürlükler ve esneklikler, topluluklar ve bireyler için yeni haklar ve yetkiler, planlama sistemini daha demokratik ve daha etkili hale getirecek reform, konut ile ilgili kararların yerel olarak alınmasını sağlayacak reform (Department for Communities and Local Government, 2011).

\section{2. İngiltere'de Yerel Yönetimlerin İșlevleri}

İngiltere yerel yönetimlerin üzerinde sıkça değişiklikler yapılmış ve yetkileri dönem dönem genişletilmiş, sınırlandırılmış veya daraltılmıştır (Parlak, 2014:33). Yerel yönetimlerin yerel ihtiyaçları karşılamak için her türlü faaliyeti gerçekleştirme yetkisi yoktur. Sadece yasa ile verilen görevleri yerine getirebilirler. Yerel yönetimler yasalarla doğrudan yetkili kılınmadıkları bir mal ve hizmeti gerçekleştirdiklerinde mahkeme bu hizmetin yürütülmesini durdurabilir ve yerel yönetimlerin iyi sunamadıkları hizmetler içinde mahkemeye 
ÇELİKSOY, Emine ve ALKAN, Aysena - Hukuki ve Örgütsel Açıdan Türkiye ve İngiltere Yerel Yönetimlerinin Karşılaştırılması

başvurulubilmektedir. Bununla birlikte yerel yönetimlerin kendi örgütleri içinde ve hizmet sunma yöntemleri açısından serbestîleri bulunmaktadır (İnaç ve Ünal, 2006:130-131).

Yerel yönetimlerin görev ve sorumluluk alanları şu şekildedir;

- Koruyucu Hizmetler: Yapısında polis hizmetleri, itfaiye hizmetleri, tüketicinin korunması ile ilgili hizmetleri içermektedir (İnaç ve Ünal, 2006:131). İngiltere'de bölge meclisleri ile bağlantılı olan polis teşkilatı, bölge meclisleri içerisinde polis komiteleri tarafından yürütülmektedir. Bu polis komitelerinin üçte ikisi meclis üyelerinden, üçte ikisi de yargıçlardan oluşmaktadır (İnaç ve Ünal, 2006:132).

- Çevre Hizmetleri: Tüketici hakları, kıyıların korunması, mezarlıklar ve cenaze hizmetleri, çevre sağlığı, zirai hizmetler ve balıkçılık hizmetleri, katı atıklar ve sokak temizliği gibi hizmetler sunmaktadır (Karasu, 2013:206).

- Ulaştırma Hizmetleri: Otoyollar, köprüler, sokak aydınlatması, trafik lambaları, toplu taşıma, havaalanları ve limanlar şeklindedir (Karasu, 2013:206).

- Eğitim, Săgllk ve Sosyal Hizmetler: Yerel yönetimlerde eğitim hizmeti birçok alan içermektedir; ilk ve orta öğretim, teknik ve sanat eğitimi, okul yemekleri, öğrenci servisleri, öğrenci kredileri, özürlü çocukların eğitimi gibi hizmetler yürütülmektedir. Sağlık hizmetleri 1974 yılına kadar yerel meclisler tarafından yürütülürken daha sonra özerk sağlık otoritelerine devredilmiştir. Kimsesizlere yer temini, spor tesisi yapımı, tiyatro, müze, galeri, kütüphane, park, bahçelerin yapımı gibi hizmetler yer almaktadır (İnaç ve Ünal, 2006:133).

\section{3. İngiltere'de Yerel Yönetimlerin Mali Yapısı}

İngiltere yerel yönetim gelirlerinin dağılımı; 1996-1997'de 75,5 milyar sterlin, 2000-2001'de 90,1 milyar sterlin, 2006-2007'de 140,7 milyar sterlin, 2010-2011'de 167,5 milyar sterlin yerel gelir bulunmaktadır (Karasu, 2013:209). 2018-2019'da ise 299 milyar sterlin yerel gelir bulunmaktadır (Ministry Of Housing Communities and Local Government, 2019). Yerel yönetimler, vergi toplarken kanunların kendilerine verdiği yetki dâhilinde hareket etmekte ve toplanan bu vergileri hizmetlerin görülmesinde harcamaktadırlar. Toplanan vergiler; bağışlar, emlak vergileri, borçlanmalar ve işletme kazançlarından oluşmaktadır. Yerel yönetimler, merkezi yönetimden özel ve genel olarak iki amaç doğrultusunda yardım alırlar (Yamaç, 2014:12). Özel amaçlı ödenekler, proje ya da hizmete özgü olarak verilmektedir. Genel amaçlı ödenekler ise, kullanılması yerel meclislerin takdirine bırakılmıştır (Karasu, 2013:211).

2018-2019 yılı verileriyle yerel kamu harcamalarında ilk sırayı \%35,3 ile eğitim almaktadır. Devamında yetişkinler için sosyal bakım, polis hizmetleri, kültürel-çevre ve planlama hizmetleri, çocuklar için sosyal bakım ve son olarak diğerleri olarak adlandırılan kategori sırasıyla yer almaktadır. Diğerleri kategorisi içerisinde ise karayolları ve ulaşım, halk sağlığı, itfaiye teşkilatı bulunmaktadır (Ministry Of Housing Communities and Local Government, 2019).

İngiltere'de yerel yönetimler yasalarda belirtilmiş olmak üzere farklı harçlar alabilmektedir. Örneğin Londra Anakent Belediyesi kent trafiğini ve hava kirliliğini azaltmak için kent merkezinde oturmayan kişilere ait araçların kent merkezine girmesi durumunda pazartesi ile cuma günleri arasında 07:00-18:00 saatleri arasında günlük £11.5 trafik sıkışıklığı ücreti adı ile harç almaktadır (Mayor of London).

\section{4. İngiltere'de Yerel Yönetimler ile Merkezi Yönetim İlişsisi}

İngiltere'de yerel yönetimler ile ilgili bir merkez örgütü hep var olmuştur. Merkezi örgüt yerel kamu hizmetleri ve yerel yönetimlerin örgütlenmesi ile ilgili politikaları belirleyen Topluluklar ve Yerel Yönetimler Bakanlığı'dır (Karasu, 2013:215).

Yerel yönetimlerin denetlenmesi mali denetim konusuna odaklanmıştır. İngiltere, yerel birimlerin idari ve mali performanslarını öncelikli tutmakta, iç ve dış denetim düzenekleri ile yerel yönetimler üzerinde etkin mali kontrol uygulamaktadır. İngiltere'de merkezi hükümet, yerel yönetimlere dış denetçi atamanın önemi ve gerekliliğini özellikle vurgulamakta, kamu kaynaklarını doğru ve verimli biçimde kullanmak için denetim yetkilerinin uygulanmasina önem vermektedir (Parlak, 2014:31).

Merkezi yönetim yerel yönetimler üzerindeki denetimini üç şekilde gerçekleştirmektedir; yasama, yürütme ve yarg1. Yasama yoluyla denetim Avam Kamarası'nın açacağı soruşturma ile ya da doğrudan yasa yapma 
yöntemiyle sağlanmaktadır. En aktif olarak başvurulan denetleme yöntemi ise yürütme yolunun kullanılmasıdır. Çevre Bakanlığı ve Başbakanlık ile yürütülen denetim ağılıklı olarak mali kaynakların yeniden düzenlenmesi, yetkilerin kısıtlanması veya doğrudan denetlenmesi yoluyla uygulanmaktadır (Parlak, 2014:33-34).

Tarihsel ve toplumsal nedenlere bağlı olarak İngiltere yerel yönetimler birimleri merkezi yönetimin denetimi altında ezilmese de özerk bir yönetim birimi olamamıştır. İngiltere'de merkezi idare ile yerel yönetimler arasındaki ilişki yerel yönetimlerin merkezi idarenin izin vermediği hiçbir şeyi yapamayacakları şeklinde en genel anlamda ifade edilebilir (Karasu, 2013:219).

\section{TÜRKIYY'DE YEREL YÖNETIMLER}

\subsection{Türkiye'de Yerel Yönetimlerin Örgütlenmesi}

Türkiye'de yerel yönetimler, anayasal statüde örgütlenmiş kurumsal düzenlemelerdir. İlk olarak tanzimat dönemiyle ortaya çıkan yerel yönetimler, farklı düzenlemeler sonrasında son halini 1982 Anayasası ile almıştır. 1982 Anayasası'nda da yerel yönetimler ayrıntılı bir şekilde düzenlenmiştir. Bu düzenlemeye göre Türkiye'de yerel yönetimler birimleri; belediyeler, köyler ve il özel idareleri olarak kabul edilmiştir. 1982 Anayasası'nın 127. maddesinde büyük yerleşim yerleri için özel yönetim biçimleri kurulabilir ifadesine dayanılarak 1984 yılında 3030 sayılı yasa ile üç ilde büyükşehir belediyeleri de kurulmuştur. 1982 Anayasası'nda İdarenin Kuruluşu başlığı ile 126. maddede merkezi idare, 127. maddede mahalli idareler düzenlenmektedir. 127. madde 126. maddeye kıyasla daha ayrıntılı bir maddedir (Görmez, 2000:85). 3030 sayılı Büyükşehir Belediyesi Kanunu ve 3194 sayılı İmar Kanunu 1980'li yıllarda çıkarılan önemli kanunlardır.

Türkiye'de yerel yönetimler anayasaya göre il, belediye veya köy halkının mahalli müşterek ihtiyaçlarını karşılamak üzere kuruluş esasları kanunla belirtilen ve karar organları, kanunda gösterilen, seçmenler tarafından seçilerek oluşturulan kamu tüzel kişileridir.

İl özel idaresi, coğrafi açıdan il düzeyinde kanunla kurulur. İl düzeyinde "il genel idaresi" ve "il özel idaresi" olmak üzere iki yönetim birimi vardır. İl genel idaresi merkezi idarenin taşra teşkilatıdır. Hem il genel idaresinin hem de il özel idaresinin başı validir. İl özel idaresi; il genel meclisi, il encümeni ve vali olmak üzere üç organdan oluşmaktadır. İl genel meclisi üyeleri, ildeki seçmenler tarafından seçilmiş̧ üyelerden oluşmaktadır ve il özel idaresinin karar organıdır. İl encümeni, il genel meclisi içerisinde karar verilecek konuların ön incelemesini yapmaktadır. Vali başkanlığında, il genel meclisinin her yıl kendi üyeleri içinden seçeceği üç üye ve valinin her yıl birim amirleri içinden seçeceği iki üye olmak üzere beş üyesi bulunmaktadır (Eryılmaz, 2015:180-185; Mecek ve Doğan, 2015:226; İzci ve Turan, 2013:128). 12.11.2012 tarihinde kabul edilen 6360 sayılı yasa ile büyükşehir belediyesinin olduğu illerde il özel idarelerinin tüzel kişiliği kaldırılmıştır.

Türkiye'de belediye yönetimleri iki kademeli olarak tesis edilmiştir. Belediyeler, genel olarak; 5393 say1l Belediye Kanununa göre kurulan belediyeler ve 5216 sayılı Büyükşehir Belediye kanununa göre kurulan belediyeler olmak üzere tasnif edilmektedirler. Hukuki düzenlemelere göre belediyeler idari ve mali özerkliğe sahiptir. Belediyenin belediye meclisi, belediye encümeni ve belediye başkanı olmak üzere üç organı bulunmaktadır. Belediye meclisi, üyelerini kanunda gösterilen usulle seçmektedir ve belediye yönetiminin karar organıdır. Belediye encümeni belediye meclisine belediye ile ilgili konularda görüş bildiren, kanunda belirtilen cezaları veren, halka açık yerlerin açılış ve kapanış saatlerini belirleyen ve diğer kanunlar ile belediye encümenine verilen işleri yapan organdır. Belediye başkanı, belediye idaresinin başı ve tüzel kişiliğinin temsilcisidir. Belediye başkanı ve meclis üyeleri 5 yıllık süre için doğrudan halk tarafindan seçilmektedir (Bayrakç1, 2018:311-313; Eryılmaz, 2015:191-199).

12.11.2012 tarihinde kabul edilen 6360 sayılı yasa ile büyükşehir belediyesinin mülki sınırları içerisinde kalan köylerin kamu tüzel kişilikleri kaldırılmış, bu durumda olan köyler mahalleye dönüşmüştür. Kendi bünyesinde köy derneği, ihtiyar meclisi ve köy muhtarı olmak üzere üç organı bulunmaktadır. Köy derneği, köyün muhtarını ve ihtiyar meclisini seçmeye hakkı bulunan köylülerin oluşturduğu topluluktur. İhtiyar meclisi, üyeleri köy derneği tarafından seçilen ve köyün yönetimi hakkında kararların alındığı bir organdır. Köy muhtarı, ihtiyar meclisi ile köy yönetiminin başıdır. Muhtarın belirtilen kanun doğrultusunda sahip olduğu haklar ise; köy işleri ile ilgili söz sahibi olmak, emir vermek ve bu emirleri uygulatmaktır (T.C. İçişleri Bakanlığ1, 2019; Mecek ve Doğan, 2015:226). 


\subsection{Türkiye'de Yerel Yönetimlerin İşlevleri}

Türkiye'de yerel yönetimler, kamusal ihtiyaçları daha etkili bir şekilde halka sunmak ve mevcut sorunlara çözüm getirmek amacıyla sürekli bir değişim ve dönüşüm süreci içerisine girmiştir. Özellikle, 1980 sonrasında önemli adımlar atılarak yerel yönetimlerin daha etkin, verimli ve çözüm odaklı birimler haline dönüştürülmesi için çalışılmış, işlevleri arttırılmıştır (Kaypak vd., 2017:1800).

İl özel idaresinin işlevleri; mahallî müşterek özellikte olan gençlik ve spor, sağlık, tarım, sanayi ve ticaret, ilin çevre düzeni planı, bayındırlık ve iskân, kültür, sanat, turizm, sosyal hizmet ve çocuk yetiştirme yurtları ihtiyaçlarının karşılanmasına ilişkin hizmetler il sınırı içindeki görevleridir. İmar, yol, su, kanalizasyon, katı atık, çevre, acil yardım, ağaçlandırma, park ve bahçe tesisine ilişkin hizmetler ise belediye sınırları dışındaki görevleridir.

Belediyenin işlevleri; şehrin altyapısı ile ilgilenir. Bunların içerisinde yapı işleri, su, kanalizasyon, ulaşım işleri bulunmaktadır. Çevre ve onun temizliği, düzenlenmesi ile ilgilenir; temizlik, katı atık, ağaçlandırma, park ve yeşil alanlar bunlara örnektir. Sosyal faaliyetler alanında; kültür, sanat, turizm ve bunların tanıtımı, gençlik ve spor, sosyal hizmet ve yardımlar bulunmaktadır. Bunların yanı sıra, itfaiye, zabıta, kurtarma, ambulans, nikâh, ekonomi ve ticaretin geliştirilmesi hizmetlerini yapar ya da yaptırır. Büyükşehir belediyeleri ile nüfusu 100.000 'in üzerindeki belediyeler, kadınlar ve çocuklar için konukevleri açmak zorundadır. Diğer belediyeler ise zorunluluk bulunmamakla birlikte bütçelerini değerlendirerek kadınlar ve çocuklar için konukevleri açabilirler.

Eğitim ile ilgili faaliyetlerine bakıldığında; okul öncesi eğitim kurumları açabilir, devlete ait okul binalarının inşaatı ile bunların bakım ve onarımını yapabilir ya da yaptırabilir. Buraların araç-gereç, malzeme ihtiyaçlarını temin edebilir. Eğitimde olduğu gibi sağlık konusunda da her türlü tesisi açabilir. Tarihi açıdan önem taşıyan mekânların korunmasını sağlayabilir; bu doğrultuda bu yerlerin bakımını ve onarımını üstlenebilir. Spor konusunda ise; ister öğrenci ister amatör spor kulüplerine gerekli malzemeyi sağlar, spor müsabakaları düzenler ve başarılı olan sporculara belediye meclisi kararı ile ödül verebilir. Belediye sınırları içerisinde olan alanlar belediyenin görev, sorumluluk ve yetki alanıdır.

Köy yönetimine ilişkin yasal düzenleme 1924 tarihli 442 sayılı Köy Kanunu'dur. Bu yasaya göre köy; cami, mektep, otlak, yaylak, baltalık gibi ortak alanları olan birbirine yakın evlerde oturan insanların bağ, bahçe ve tarlalarıyla birlikte yer aldıkları, nüfusu iki bini aşmayan yerleşim birimidir. Köy Kanunu'na göre köye ait işlerin o köyde yaşayan insanlar tarafından yerine getirilmesi gerekmektedir. Köydeki işler mecburi işler ve isteğe bağlı işler olmak üzere ikiye ayrılmaktadır. İsteğe bağlı işlerin yapılmaması halinde herhangi müeyyide yokken mecburi işlerin yapılmaması halinde müeyyide öngörülmektedir (T.C. İçişleri Bakanlığı, 2019; Toprak, 2014:137-138).

Köyün işlevleri; sağlık, temizlik, tarım, imar ve eğitim alanlarını bünyesinde bulundurmaktadır. Sağlık ve temizlik alanında; köy içinde oluşan bataklık ve su birikintilerini kurutmak, köye içme suyu getirmek ve mevcut tüm su kanallarını her daim temiz tutmak bu alandaki zorunlu işleridir. İmar ve eğitim alanında; köy içerisine yollar, okul, mescit ve konuk odası yapmak ya da yaptırmak bu alandaki zorunlu diğer görevleri arasındadır (Ery1lmaz, 2015:218-219).

Türkiye'de köyler yeterli finansal kaynaklara sahip olmadıkları için merkezi idarenin mali ve hizmet desteği ile varlıklarını devam ettirmektedirler. Köylerin hizmet taleplerinin öncelik sıralaması köyler arasında farklılıklar göstermektedir. Kütahya özelinde yapılan ve Türkiye'ye 1şık tutacağı düşünülen bir çalışmada sırasıyla yol yapım ve bakım, sağlık hizmetleri, içme suyu ve tarımsal amaçlı kullanma suyu hizmetlerinin ençok talep gören kamu hizmetleri olduğu; elektrik, eğitim hizmetleri, yaşlilara yönelik hizmetler, çöp ve kanalizasyon, iletişim ve internet hizmetleri ile çocuk parkı yapımı gibi hizmetlerin ise daha az düzeyde talep edilen hizmetler olduğu tespit edilmiştir (Uysal ve Mecek, 2015:1182). 


\subsection{Türkiye'de Yerel Yönetimlerin Mali Yapısı}

İl özel idaresine ilişkin mali esaslar 5302 sayılı İl Özel İdaresi Kanunu'nun beşinci bölümünde düzenlenmiştir. İl özel idaresinin gelirleri; kanunda uygun görülen vergi, resim, harç, katılma payları, genel bütçenin içerisinden vergi gelirlerine ayrılan paylar, taşınır ve taşınmaz mallardan elde edilecek kira ve satış gelirleri, ceza gelirleri ve bağışlardır.

İl özel idarelerinin giderleri; il özel idaresine ait binaların, araçların, malzemelerin temini ve onarımı için yapılan giderler, kendi personeline yapmış olduğu maaş, yolluk ve personelin eğitimine ait giderler, alt yapının yapılması ve bunların bakım giderleri, faiz ve borçlanma ya da sigorta giderleri, tören-tanıtım gideri, sosyal kültürel ya da bilimsel faaliyetler için yapılan giderlerdir.

Valinin hazırlamış olduğu bütçe tasarısı, eylül ayı başında il encümenine sunulur ve il encümeni kendi görüşü ile birlikte il genel meclisine sunar. Burada il genel meclisi aynen ya da değiştirerek bütçeyi kabul eder. Bununla birlikte meclis bütçe düzenini değiştirecek düzeyde gider ve gelirleri yeniden düzenleyemez. Bütçe tasarısı bu süre içinde kesinleşmez ise vali, kendi görüşüyle beraber durumu İçişleri Bakanlığı'na iletir. İçişleri Bakanı otuz gün içerisinde nihai kararı vermekle yetkili ve görevlidir.

Belediyeye ilişkin mali esaslar 5393 sayılı Belediye Kanunu'nun beşinci bölümünde düzenlenmiştir. Belediyelerin gelirleri; kanunda uygun görülen vergi, resim, harç, katılma payları, genel bütçenin içerisinden vergi gelirlerine ayrılan paylar, taşınır ve taşınmaz mallardan elde edilecek kira ve satış gelirleri, ceza gelirleri ve bağışlardır. Türkiye'de belediyelerin kendilerinin topladıkları yedi ayrı tür vergi vardır. Bunlar; emlak vergisi, ilan ve reklam vergisi, eğlence vergisi, haberleşme vergisi, elektrik ve hava gazı tüketim vergisi, çevre ve temizlik vergisi, yangın ve sigorta vergisidir (Erdoğan, 2018:164-172).

Belediyelerin giderleri; belediyeye ait binaların, araçların, malzemelerin temini ve onarımı için yapılan giderler, kendi personeline yapmış olduğu maaş, yolluk ve personelin eğitimine ait giderler, alt yapının yapılması ve bunların bakım giderleri, belediyenin itfaiye ve zabıta hizmetlerinin giderilmesi için yapılacak giderler, mezarlık temin edilmesi ve bunun bakımına ait giderler, durumu kötü olan insanlara yapılacak sosyal yardımlar, törentanıtım gideri, sosyal kültürel-sanatsal ya da bilimsel faaliyetler için yapılan harcamalar, imar düzenleme giderleri şeklindedir.

Belediye başkanının hazırlamış olduğu bütçe tasarısı eylül ayının birinci gününden önce encümene sunulur. Sonrasında da Çevre ve Şehircilik Bakanlığına gönderilir. Çevre ve Şehircilik Bakanlı̆̆ı belediye bütçe tahminlerini konsolide eder ve 5018 sayılı Kamu Malî Yönetimi ve Kontrol Kanunu uyarınca merkezi yönetim bütçe tasarısına eklenmek üzere eylül ayı sonuna kadar Maliye Bakanlığına bildirir. Encümen, bütçe için görüşünü bildirerek belediye meclisine sunar. Burada meclis aynen ya da değiştirerek bütçeyi kabul eder. Bütçe belediyenin stratejik planı ile performans programı dikkate alınarak hazırlanmalıdır.

Köylerin mali yapıs1; köy bütçesi ile oluşturulur. Köye ait olan bir yıllık gelir ve gider tahminleri ile yardımlaşmaya ait konuları içerir. Oluşturulan köy bütçesi öncelikle köy ihtiyar meclisine ait karar ile kabul edilir ve bütçenin durumuna göre kaymakam ya da vali tarafından onaylandığ takdirde kesinleşmiş kabul edilir. Muhtar tarafından toplanan köy gelirlerine karşılık Maliye tarafından basılmış makbuz verilir. Milli bankalarda bulunan köy paraları, köy tüzel kişiliği adına açılacak cari hesap adı altında bulundurulur. Muhtarın onayıyla gerçekleşen köy borcu pullu senet, fatura ya da makbuz ile köy sandığından ödenir (T.C. İçişleri Bakanlığı, 2019).

\subsection{Türkiye'de Yerel Yönetimler ile Merkezi Yönetim İlişkisi}

Yerel yönetimlerin görevlerini yerine getirirken suç işledikleri yönünde şüphe oluşması durumunda haklarında soruşturma açılabilir veya kovuşturma başlatılabilir. Soruşturma açılan veya kovuşturma başlatılan yerel yönetim organları veya bunların üyelerini, İçişleri Bakanı, kesin hükme kadar tedbiren görevinden uzaklaştırabilir. Yerel yönetimler üzerinde merkezi idarenin idari vesayet yetkisi bulunmaktadır. Yerel yönetimler üzerinde idari vesayet yetkisini İçişleri Bakanı kullanmaktadır. İdari vesayet T.C. 1982 Anayasası'na göre mahalli hizmetlerin, idarenin bütünlügü ilkesine uygun olması, kamu görevlerinde birliği sağlanması, toplum yararının korunması ve mahalli ihtiyaçların gereği gibi karşılanması amacıyla dört amaç için yapılır. Yerel yönetimlerin mali işlemleri Türkiye Büyük Millet Meclisi adına Sayıştay tarafından denetlenir (Eryılmaz, 2015:179). 
Merkezi yönetim ile yerel yönetimler arasındaki mali ilişkilerin en önemli ayağını merkezi idare tarafından toplanan vergilerden yerel yönetimlere verilen paylar oluşturmaktadır. Aynı zamanda Hazine ve Maliye Bakanlığı'da yerel yönetimlere yardım yapabilir. Yıllara göre farklılaşmakla birlikte yerel yönetimlerin bütçelerinin $\% 70$ ile \%80'i arasındaki oran bu merkezi idare tarafından yerel yönetimlere aktarılmaktadır. Merkeze olan bu mali bağımlılık yerel yönetimlerin hizmet sunma gücü ve kapasitesini engellemektedir.

Merkezi yönetim ile yerel yönetimler arasındaki mali ilişkiler, yerel yönetimlerin doğrudan hizmetleri sunabilmesine ya da sunamamasına yol açabilmektedir. Yeterli mali kaynağı olmayan bir yerel yönetim organının etkin ve verimli bir mal ve hizmet sunması imkânsızdır. Mali yeterlilik sağlandığında yerel yönetimler sunabilecekleri en mükemmel şekilde mal ve hizmet sunabilecektir demek ne kadar isabetsiz olacaksa yerel yönetimlerin mal ve hizmet sunması ile mali güçleri arasında doğrudan bir ilişki yoktur demek de o kadar isabetsiz olacaktır.

Yerel yönetimlerde harcama yetkisi verilen görevlilerin mali sorumluluğu vardır. Belediye başkanı için de aynı sorumluluk söz konusudur. Bütçenin de verimli, ekonomik ve isabetli bir şekilde kullanılması gerektiği yasal olarak güvence altına alınmışıı. İçişleri Bakanlığı tarafından yayınlanan Mahalli İdareler Faaliyet Raporu'nda yerel yönetimlerin bilgileri paylaşılmaktadır. Bu raporlar düzenli olarak, yıl bazlı yayınlanmaktadır.

Türkiye'de kamu hizmetlerinin merkezi yönetim ve yerel yönetimler arasında paylaştırılmasında en genel kriter sunulacak mal veya hizmetin mahalli müşterek ihtiyaç olup olmamasıdır. Bu kriter hizmetin yararlanıldığı alan ve ekonomik boyut ile diğer ihtiyaçlardan ayrılmaktadır. Fakat 1982 Anayasası'nda yer alan mahalli müşterek ihtiyaçlar ibaresinin ekonomik boyuttan ziyade hizmetlerin alansal dağılımı ile ilgili olduğu söylenebilir (Özer ve Ayhan, 2018:442). Bunlarla birlikte Türkiye'de son 15 yıl içerisinde yerel yönetimlerin mali özerkliğinin genişletilmesi ve gereksiz denetim ve gözetimin azaltılması yönünde olumlu bir tutum izlenilmiştir. $\mathrm{Bu}$ durumda Avrupa Yerel Yönetimler Özerklik Şartı'nın kurallarına uyum çabasının rolü de bulunmaktadır.

Türkiye'de yerel yönetimler ve merkezi yönetim arasındaki ilişkilerde denge, son zamanlarda bazı yasal ve kurumsal düzenlemeler ile yerel yönetimler lehine değişmişse de bu denge, genel anlamda merkezi yönetimin halen baskınlığı ile devam etmektedir (Özer ve Ayhan, 2018:446).

\section{4. İNGILTERE İLE TÜRKIYE YEREL YÖNETIM KARŞILAȘTIRMASI}

İngiltere yerel yönetim sistemi ile Türkiye yerel yönetim sistemi arasında görünen benzerlikler kadar farklılıklar da bulunmaktadır. İngiltere yerel yönetim yapılanması il, bölge ve köy olarak üç organa ayrılırken Türkiye'de bu durum il özel idaresi, belediye ve köy olarak üç organa ayrılmaktadır. İngiltere'de Türkiye'den farklı olarak ve kendine özgü bir düzenlemeye tabi olan Büyük Londra Yönetimi bulunmaktadır. Türkiye'de ise hiçbir ilin bu şekilde kendine özgü bir düzenlemesi bulunmamaktadır. Bununla birlikte hem başkent Ankara'da hem de diğer 29 büyükşehirde büyükşehir belediyeleri bulunmaktadır.

Her iki ülkede de yerel yönetimler benzer görev ve sorumlulukları yerine getirmektedir. Bu durumun oluşmasında hem mahalli hem de müşterek ihtiyaçların benzer olmasının rolü vardır. Örneğin; imar, çevre ve yeşillendirme, mezarlık ve cenaze, sokak temizliği, toplu taşıma, eğitim, sağlık gibi. Fakat farklı olarak polis teşkilatı ele alınabilir. İngiltere'de polis teşkilatı yerel yönetim birimleri altında bulunmaktadır. Bu durum Türkiye'de farklıdır. Türkiye'de polis teşkilatı İçişleri Bakanlığı'na bağlı bir genel müdürlüktür. Merkezde daire başkanlıkları, taşrada ise il ve ilçe emniyet müdürlüğü ile ilçe emniyet amirlikleri olarak örgütlenmiş durumdadır. Türkiye'de emniyet hizmetleri yerel yönetimlerin sorumluluğu altında değildir, merkezi idare tarafından ülke düzeyinde, il ve ilçe teşkilatları ile de taşrada yerine getirilmektedir (T.C. İçişleri Bakanlığı Emniyet Genel Müdürlüğ̈̈, 2019).

Mali açıdan baktığımızda ise İngiltere'nin eğitime daha fazla yatırım yapmakta olduğunu görmekteyiz. Türkiye'de yerel yönetimlerin eğitime ciddi bütçeler ayırdıklarını söyleyemeyiz. Bunun en önemli nedeni Türkiye'de eğitimin sunumundan yerel yönetimler değil, merkezi idare sorumludur. Her iki ülkenin mali yapısında vergiler önemli bir yer edinmekte ve her iki ülke de gerek görüldüğünde merkezi yönetimden mali destek almaktadır.

İngiltere yerel yönetim gelirlerinin dağılımı incelendiğinde devlet tarafindan aktarılan miktarlar şu şekilde ayrılmaktadır; gelir desteği, yeniden dağıtılan vergi, iç güvenlik (polis) hizmetleri ödeneği, özel amaçlı ödenekler ve diğer şeklinde. 1996-1997'de devlet tarafından aktarılan toplam miktar 48.9 milyar sterlin, 20002001'de 54.4 milyar sterlin, 2006-2007'de 85.2 milyar sterlin, 2010-2011'de 107.4 milyar sterlin (Karasu, 2013:209) ve 2018-2019'da ise 48.1 milyar sterlin şeklindedir (Ministry Of Housing Communities and Local 
Government, 2018-2019). Verilen yıllara bakıldığında İngiltere'nin yerel yönetim gelirlerinin dağılımında devlet tarafından aktarılan bütçe, yerel kaynaklardan daha fazladır. Yerel yönetimlerin kendi kaynakları içerisinde yer edinen vergi gelirleri ise şu şekildedir; 1996-1997'de 10.6 milyar sterlin, 2000-2001'de 14.2 milyar sterlin, 2006-2007'de 22.4 milyar sterlin, 2010-2011'de 26.1 milyar sterlin (Karasu, 2013:209) ve 20182019 'da ise 29,6 milyar sterlin şeklindedir (Ministry Of Housing Communities and Local Government, 20182019). İngiltere yerel yönetim gelirlerinde en önemli destek merkezi idare tarafindan sağlanmaktadır. İkinci büyük gelir kalemi ise vergilerdir. Merkezi idareden yüklü miktarda maddi destek alan yerel yönetimlerin mali özerklikleri bu kapsamda düşünülmelidir.

Türkiye'de yerel yönetimlerin en önemli gelir kaynakları merkezden sağlanan genel bütçe gelirleri üzerinden verilen paylar ve bunun yanında devlet yardımlarından oluşmaktadır. 2006 ila 2018 yılları için yerel yönetimlerin en büyük harcama kalemi personel giderleri, mal ve hizmet alım giderleri, sermaye giderleri olmuştur. Yerel yönetim gelirlerinin yerel bütçe içerisindeki payında ise yine 2006 ila 2018 yılları arasına bakıldığında ilk sırayı faizler, paylar ve cezalar almaktadır (Yüksel, 2019:273-280). Veriler göstermektedir ki Türkiye'de önemli gelir kaynağı merkezden sağlansa da faizler, paylar ve cezalar yerel yönetim gelirleri içerisinde önemli bir yere sahiptir. Mali özerklikten konusunda devlet desteğinin yerel yönetimler gelir kaynakları içerisinde oldukça büyük yer edindiği unutulmamalıdır.

Tablo 1. İngiltere ve Türkiye Yerel Yönetim Sistemleri

\begin{tabular}{|c|c|c|}
\hline & INGILTERE & TÜRKIYYE \\
\hline Yerel Yönetimler & $\begin{array}{l}\text { İl } \\
\text { Bölge } \\
\text { Köy (County, District, Parish) }\end{array}$ & $\begin{array}{l}\text { İl Özel İdaresi } \\
\text { Belediye } \\
\text { Köy }\end{array}$ \\
\hline $\begin{array}{l}\text { Yerel Yönetimlerin Hukuki } \\
\text { Dayanakları }\end{array}$ & $\begin{array}{l}\text { Anayasa'da düzenlenmemiş, ilgili yasalar ile } \\
\text { düzenlenmiştir }\end{array}$ & Anayasa ve ilgili yasalar ile düzenlenmiştir. \\
\hline $\begin{array}{l}\text { Yerel Yönetimlerin Görev } \\
\text { ve Sorumlulukları }\end{array}$ & $\begin{array}{l}\text { İmar } \\
\text { Çevre ve Peyzaj } \\
\text { Mezarlık ve Cenaze } \\
\text { Sokak Temizliği } \\
\text { Toplu Taşıma } \\
\text { Eğitim } \\
\text { Sağlık } \\
\text { Polis Teşkilatı } \\
\text { Konut güvenlik } \\
\text { Koruyucu hizmetler, planlı kalkınma vb. }\end{array}$ & $\begin{array}{l}\text { İmar } \\
\text { Çevre ve Peyzaj } \\
\text { Mezarlık ve Cenaze } \\
\text { Sokak Temizliği } \\
\text { Toplu Taşıma } \\
\text { Eğitim } \\
\text { Sağlık } \\
\text { Sosyal hizmetler } \\
\text { Altyap hizmetleri vb. }\end{array}$ \\
\hline Yerel Yönetimlerin Gelirleri & $\begin{array}{l}\text { Emlak Vergileri, Bağışlar, Borçlanmalar, } \\
\text { Hükümet Yardımları, İşletme Kazançları, } \\
\text { Diğer } \\
\text { Gelirler }\end{array}$ & $\begin{array}{l}\text { Vergiler, Harçlar, Harcamalara Katılma Payları, } \\
\text { Genel Bütçe Gelirlerinden Ayrılan Paylar, Bağışlar, } \\
\text { Borçlanmalar }\end{array}$ \\
\hline $\begin{array}{l}\text { Bütçe İçindeki En Yüksek } \\
\text { Gider Kalemi }\end{array}$ & Eğitim Giderleri & Personel Giderleri \\
\hline $\begin{array}{l}\text { Yerel Yönetimlerin } \\
\text { Denetimi }\end{array}$ & $\begin{array}{l}\text { Parlamentonun Denetimi } \\
\text { Vesayet Denetimi } \\
\text { Hizmetle İlgili Bakanlık Denetimi } \\
\text { Yargisal Denetim }\end{array}$ & $\begin{array}{l}\text { Vesayet Denetimi } \\
\text { Yargısal Denetim } \\
\text { Mali Denetim (Sayıştay) } \\
\text { Etik Denetim } \\
\text { Ombudsman Denetimi }\end{array}$ \\
\hline $\begin{array}{l}\text { Başkente Özgü Yerel } \\
\text { Yönetimler }\end{array}$ & $\begin{array}{l}\text { Kendine özgü düzenlemeye tabi Büyük Londra } \\
\text { Yönetimi bulunmakta ve anakent olarak } \\
\text { adlandırılmaktadır. }\end{array}$ & $\begin{array}{l}\text { Ankara başkent olarak adlandırılmakta ve Ankara } \\
\text { ile beraber } 30 \text { büyükşehir bulunmaktadır. }\end{array}$ \\
\hline
\end{tabular}

Kaynak: Usta vd., 2017:77’den yararlanılarak hazırlanmıştır.

Yerel yönetimlerin merkezi yönetim ile ilişkilerine bakıldığında, İngiltere'de Türkiye gibi üniter bir yapıya sahip olmasına rağmen yerel yönetimler daha köklüdür. Türkiye'de yerel yönetimlerin mevcut halinde tarihi faktörler ve ülke içi şartların etkili olduğunu söyleyebiliriz. 


\section{SONUÇ}

İngiltere'de yerel yönetimler sürekli değişim içindedir. Hükümetlerin reform programları içerisinde yer almaktadır. Reform programları ile yerel yönetim sistemi sadeleştirilmeye çalışılmaktadır. Bu çalışmalara rağmen Türkiye ile kıyaslandığında Türkiye'ye göre daha karmaşık bir yerel yönetimler yapısına sahiptir diyebiliriz. İngiltere'de özerk gözüken yerel yönetimler üzerinde aslında merkezi yönetimin vesayetinin olduğunu söyleyebiliriz. Yerel yönetimlerin merkezi yönetimden özel ve genel amaç doğrultusunda mali yardım alabilmeleri, politikaları belirleyen Topluluklar ve Yerel Yönetimler Bakanlığı'nın bulunması, Çevre Bakanlığı ve Başbakanlık ile birlikte yürütülen bir denetimin bulunması merkezi idarenin vesayetini açıklamaktadır. Bunlarla birlikte yerel yönetimler genel yetkili idareler değildir. Yerel yönetimler merkezi idarenin izin verdiği her şeyi yapabilmektedir. Kendi kendini yetkilendirmesi halinde mahkemeler devreye girmektedir. Aynı zamanda başarısız hizmet sundukları zaman da mahkemeler tarafindan yargılanabilmektedir.

Türkiye'de yerel yönetim sistemleri daha açık ve anlaşılır bir sisteme sahiptir. Yerel yönetimlere ilişkin düzenlemeler zaman zaman yapılmakla birlikte 2000'li yıllarda gerçekleştirilen yerel yönetim reformları halen yürürlüktedir. Bu reformlar kapsamında çıkarılan belediye kanunu, büyükşehir belediyesi kanunu ve il özel idaresi kanunu yerel yönetimleri hem yetki hem de mali anlamda güçlendirmek amacı taşımaktadır. Bununla birlikte ülkenin içinde bulunduğu siyasi durum ve güvenlik sorunları yerel yönetimlere zaman zaman endişe ile yaklaşılmasına yol açmaktadır. Çeşitli terör örgütleri ile yerel yönetimlerin ilişki içinde bulunabilecekleri tereddütü vatandaşların geçmiş tecrübelere dayanarak hafızalarında yerini korumaktadır. Hem büyükşehir belediyeleri hem de belediyeler politize örgütler oldukları eleştirisi almaktadırlar.

Türkiye'de yerel seçmenler belediye başkanını ve eğer büyükşehirde ikamet ediyor iseler büyükşehir belediye başkanını seçme hakkına sahiptir. İngiltere'de ise durum böyle değildir. İngiltere yerel yönetimlerin kendi örgütsel yapıları dikey hiyerarşik değildir. Türkiye'de ise yerel yönetimlerin içerisinde bir hiyerarşi bulunmaktadır. Türkiye'de yerel yönetimlerde örgütsel merkeziyetçilik hakimdir.

İngiltere ve Türkiye'de yerel yönetimler üç kademeye ayrılmıştır. Adlandırılmaları biraz farklılık gösterse de görev ve yetki olarak birbirlerine benzer durumdadırlar. İngiltere'de anakent olarak ifade edilen yerel yönetim birimi Türkiye'de büyükşehir belediyesi ile büyük oranda örtüşmektedir. Sayısal olarak bakıldığında İngiltere'de toplamda yedi anakent bulunurken Türkiye'de bu durum otuz büyükşehir belediyesi şeklindedir.

İki ülke örneğine baktığımızda İngiltere Türkiye’ye göre daha özerk ve daha işlevsel bir yerel yönetime sahiptir. Bunun en önemli nedenlerinden birisi İngiltere'nin idari yapısında yerel yönetimleri 1215 y1lında görürken, Türkiye'nin idari yapısında yerel yönetimleri 1876 yılında görüyoruz. İngiltere'de yerel yönetimler uzun tecrübeler sonucunda bugünkü yapısına ulaşmıştır diyebiliriz.

Tarihsel sürece bakıldığında, İngiltere'de 1215 Magna Carta ile başlayan yerel yönetimler belli bir duraksamadan sonra sürekli olarak yapılan reform hareketleri ile geliştirilmeye, değiştirilmeye çalışılmıştır. Türkiye'de ise yerel yönetimler hem yıl anlamında yaklaşık 600 yıl sonra idari yapıya eklenmiş hem de Osmanlı Devleti'nin merkeziyetçi yapısı içerisinde gelişim imkânı bulamamıştır. Cumhuriyetin ilanından sonra Türkiye'de de Osmanlı'dan miras kalan güçlü merkezi yönetim anlayışı uzun zaman hüküm sürmüştür. Yerel yönetimler mevcut hallerine bu şartlar altında gelmişlerdir.

\section{KAYNAKÇA}

ARSLAN, Erkan (2018), “İngiltere'de Yerelleşme Politikaları ve Yerel Yönetimler”, İnsan ve Toplum Bilimleri Araştırmaları Dergisi, S.7(4), ss.2868-2884.

BAYRAKÇI, Erdal (2018), “Belediye Yönetimi”, Yerel Yönetimler (Ed. Kemal Görmez, Hasan Yayl1), Orion Kitapevi Yayını, Ankara, ss.305-345.

BAYRAKÇI, Erdal (2019), Yerel Yönetimler Ders Notları, Dizgi Ofset, Konya.
BBC NEWS (1998), "Overwhelming Vote for Mayor, http://news.bbc.co.uk/2/hi/special_report/1998/london_referendum/89327.stm 06.03.2020).
ÇİÇEK, Yeter (2014), “Geçmişten Günümüze Türkiye'de Yerel Yönetimler”, KSÜ Sosyal Bilimler Dergisi, S.(11)1, ss.53-64.


DEPARTMENT FOR COMMUNITIES AND LOCAL GOVERNMENT (2011), Annual Report and Accounts 2010-11, House of Commons, Londra.

ERDOĞAN, Oğuzhan (2018), "Başkanlıkla Yönetilen Üniter Devletlerde Yerel Yönetimler: Peru, Filipinler, Güney Kore, Kenya ve Türkiye”, Yayımlanmamış Doktora Tezi, Aksaray Üniversitesi Sosyal Bilimler Enstitüsü, Aksaray.

ERYILMAZ, Bilal (2015), Kamu Yönetimi, Umuttepe Yayınlar1, Kocaeli, 8.Bask1.

GÖRMEZ, Kemal (2000), “Demokratikleşme Açısından Merkezi Yönetim-Yerel Yönetim İlişsileri”, Gazi Üniversitesi İiBF Dergisi, S.(2)1, ss.81-88.

İNAÇ, Hüsamettin ve ÜNAL, Feyzullah (2006), “íngiltere'de Yerel Yönetimler”, Dumlupınar Üniversitesi Sosyal Bilimler Dergisi, S.16, ss.125-140.

IZCI, Ferit ve TURAN, A. Menaf (2013), “Türkiye'de Büyükşehir Belediyesi Sistemi ve 6360 Sayılı Yasa ile Büyükşsehir Belediyesi Sisteminde Meydana Gelen Değişimler: Van Örneği”, Süleyman Demirel Üniversitesi İïBF Dergisi, S.18(1), ss.117-152.

KARASU, Koray (2013), “íngiltere'de Kamu Yönetimi”, Kamu Yönetimi Ülke İncelemeleri (Ed. Koray Karasu), İmge Kitabevi, Ankara, ss.145-293.

KAYPAK, Şafak, YILMAZ, Vedat ve BİMAY, Muzaffer (2017), “Dijital Çağda Yerel Yönetimler”, Süleyman Demirel Üniversitesi İktisadi ve İdari Bilimler Fakültesi Dergisi, S.22(Kayfor 15 Özel Sayıs1), ss.1798-1813.

KOÇAK, Yüksel (2008), Karşıllaştırmalı Yerel Yönetimler, Orion Yayınları, Ankara.

MAYOR OF LONDON (Tarihsiz), Congestion Charge, https://tfl.gov.uk/modes/driving/congestioncharge?cid=pp020 (Erişim Tarihi: 14 Ekim 2019).

MECEK, Mehmet ve DOĞAN, Hüsna (2015), "İstihdam Açısından Yerel Yönetimlerin Organizasyon Yapısı ve Personel Yönetimi", İdari ve Mali Açıdan Türkiye'de Yerel Yönetimler (Ed. Mehmet Mecek, Mesut Doğan, Bekir Parlak), Bekad Yayınları, Antalya, ss.211-273.

MINISTRY OF HOUSING (2019), "Local Authority Revenue Expenditure and Financing: 2018-19 Provisional Outturn", Communities and Local Government, England, https://assets.publishing.service.gov.uk/government/uploads/system/uploads/attachment_data/file/846366 /Local_authority_revenue_expenditure_and_financing_England_2018_to_2019_provisional_outturn.pdf (Erişim Tarihi: 06.03.2020).

OAKLAND, John (2002), British Civilization, Rutledge Press, London, Fifth Edition, www.ff.ues.rs.ba (Erişim Tarihi: 25.03.2020).

ÖNEN, Mustafa ve GÜNGÖR, Mustafa (2018), "Yerel Yönetim ve Merkezi Yönetim İlişkileri”, Kamu Yönetimi Tartışmaları (Ed. Mehmet Akif Özer, Ufuk Ayhan), Gazi Kitabevi, Ankara.

PARLAK, Bekir (2014), “Avrupa Birliği Perspektifinden Merkezi Yönetim - Yerel Yönetim İlişkileri”, Tesam Akademi Dergisi, S.(1)1, ss.7-40.

PARLAK, Bekir (2015), “Yerel Yönetimler: Kavramsal ve Kuramsal Çatı”, İdari ve Mali Açıdan Türkiye'de Yerel Yönetimler (Ed. Mehmet Mecek, Mesut Doğan, Bekir Parlak), Bekad Yayınları, Antalya, ss.5-34.

T.C. İÇiŞLERİ BAKANLIĞI (2019), Emniyet Genel Müdürlüğü Teşkilat Şeması, Kurumsal Web Sayfası, (Erişim Tarihi: 23.11.2019).

T.C. İÇIŞLERİ BAKANLIĞI (2019), “Köyler”, İller İdaresi Genel Müdürlüğü İstatistikleri, https://www.icisleri.gov.tr/illeridaresi/koyler1 (Erişim Tarihi: 14.10.2019).

T.C. İÇIŞLERİ BAKANLIĞI (2019), Kurumsal Web Sayfası, https://www.icisleri.gov.tr/ (Erişim Tarihi: 21.03.2020).

T.C. KALKINMA BAKANLIĞI (2014), 10. Kalkınma Planı 2014-2018 Yerel Yönetimler Özel İhtisas Komisyonu Raporu 2023, Kalkınma Bakanlığı Yayını, Ankara.

TOPRAK, Zerrin (2014), Yerel Yönetimler, Siyasal Kitabevi, Ankara, 9.Bask1. 
ÇELIKSOY, Emine ve ALKAN, Aysena - Hukuki ve Örgütsel Açıdan Türkiye ve İngiltere Yerel Yönetimlerinin Karşılaştırılması

UK PARLIAMENT (2016), Referendums held in the UK, https://www.parliament.uk/getinvolved/elections/referendums-held-in-the-uk/ (Erişim Tarihi: 06.03.2020).

USTA, Sefa, AKMAN, Elvettin ve KOCAOĞLU, Mustafa (2017), "Yerelleşme-Merkezileşme Tartışmaları Ekseninde Yerel Yönetimlerde Reform: Ingiltere ve Türkiye Üzerine Mukayeseli Bir Analiz”, Selçuk Üniversitesi Sosyal Bilimler Meslek Yüksekokulu Dergisi, S.(20)1, ss.68-78.

UYSAL, Yusuf ve ATMACA, Yıldız (2018), “Türkiye'deki Merkezi ve Yerel Yönetim İlişkilerinin Yönetişim Modeli Çerçevesinde Değerlendirilmesi”, Uluslararası Yönetim Akademisi Dergisi, S.1(3), ss.411-424.

UYSAL, Yusuf ve MECEK, Mehmet (2015), "Köylere Sunulan Kamu Hizmetlerinin Nitelik ve Niceliği: Kütahya İli Örneği”, 13. Kamu Yönetimi Kongresi (Kayfor'13) Bildiriler Kitabı (Ed. Mehmet Akif Çukurçayır, Hacer Tuğba Eroğlu, Hayriye Sağır, Mücahit Navruz), Selçuk Üniversitesi İİBF Yayınları, Konya, 15-17 Ekim 2015, ss.1169-1183.

YAMAÇ, Müzehher (2014), “İngiltere'de Yerel Yönetimler”, Namık Kemal Üniversitesi Sosyal Bilimler Metinleri Dergisi, S.4, ss.1-28.

YÜKSEL, Cihan (2019), “Türkiye'de Yerel Yönetimlerin Mali Yapısındaki Dönüşüm”, Maliye Araştırmaları Dergisi, S.(3)5, ss.267-286. 